1976

\title{
Papers on Paleo-Indian Archaeology in Texas: I
}

\author{
Thomas R. Hester \\ Center for Archaeological Research
}

Follow this and additional works at: https://scholarworks.sfasu.edu/ita

Part of the American Material Culture Commons, Archaeological Anthropology Commons, Environmental Studies Commons, Other American Studies Commons, Other Arts and Humanities Commons, Other History of Art, Architecture, and Archaeology Commons, and the United States History Commons

Tell us how this article helped you.

This Article is brought to you for free and open access by the Center for Regional Heritage Research at SFA ScholarWorks. It has been accepted for inclusion in Index of Texas Archaeology: Open Access Gray Literature from the Lone Star State by an authorized editor of SFA ScholarWorks. For more information, please contact cdsscholarworks@sfasu.edu. 


\section{Papers on Paleo-Indian Archaeology in Texas: I}

Creative Commons License

(c) $)$ (i) @

This work is licensed under a Creative Commons Attribution-NonCommercial 4.0 International License 


\section{PAPERS ON}

\section{PALEO-INDIAN ARCHAEOLOGY IN TEXAS: I}

\section{CENTER FOR ARCHAEOLOGICAL RESEARCH}

THE UNIVERSITY OF TEXAS AT SAN ANTONIO

SPECIAL REPORT NO. 3

1976 


\title{
Center for Archaeological Research
}

The University of Texas at San Antonio.

\section{5}

\author{
Thomas R. Hester, Director
}

\section{Spectal Reports}

Pibligations dea ing whth he archaeology of Texas and Mesoamer ca.

No 1 (1975) 1 Some Aspects of Late Prehistoric and Protohistoric Archaeology w Southern Texas' (By Thomas R. Hester

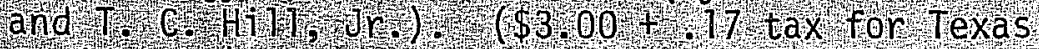
restdents.). Second printing 1977 .

No. $2.2(1197$

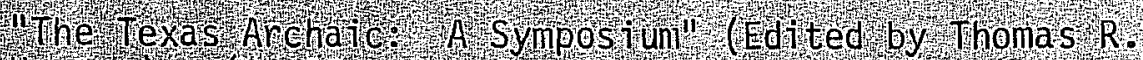
Hester) Second printing, 1978 .

No. $3 .(1976)$

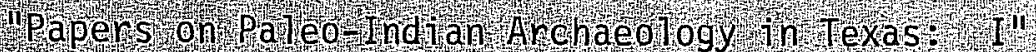
(Papers by T. R. Rester and W. W. Birming ham).

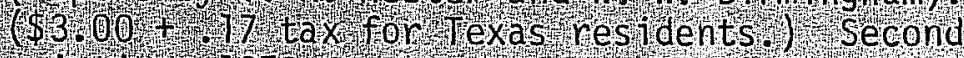
print $12 \mathrm{sg}$, 1978

No. $4.6(196)$

Whara Lithics. Papers from the 1976 Belize Fleld Syripes lum (Edtted by Nornan Hammond and Thomas R. Hester) ( $\$$ ( 8.00 + 44 tax for Texas residents.)

No. $5 .(797)$

Hop 111: Culture and C1 imatic Change in Centra 1 Texas (By Joel Gunn and Royce Mahula). Out of print.

No. $6 .(1978)$

"Background to the Archaeology of Chaparrosa Ranch, Southern Texas" (By Thomas R. Hester). Vol. 1, Studies in the Archaeology of Chaparrosa Ranch. $(\$ 4.00+.22$ tax for texas residents [tentative].) Expected publication date Summer 1978.

No. 7 (1978) The Mariposa site: A Late Prehistoric Site on the R10 Grande Plain of Texas" (By John Montgomery). V01.2, Studies in the Archaeology of Chaparrosa Ranch. $(\$ 8.00+.44$ tax for Texas residents [tentative].) Expected publication date summer 1978. 
PAPERS ON PALEO-INDIAN ARCHAEOLOGY IN TEXAS: I

Center for Archaeological Research The University of Texas at San Antonio

Special Report No. 3

1976

Second Printing 1978 
TABLE OF CONTENTS

Page

Preface

$i i$

Late Pleistocene Aboriginal Adaptations in Texas

1 by Thomas R. Hester

Late Pleistocene Archaeological Remains From the

15 Johnston-Heller Site, Texas Coastal Plain by William W. Birmingham and Thomas R. Hester 


\section{PREFACE}

This third number in the Center's Special Report series contains two papers dealing with Paleo-Indian archaeology in Texas. Two additional papers dealing with this topic have recently been submitted. One involves a detailed review of the PlainviewGolondrina typological problem (authored by Thomas C. Kelly), and a second (written by Jules A. Jaquier), describing the bifacial implements from the Johnston-He1ler site (41 VT 15; see this volume). We intend to publish these papers in the Special Report series at a later date, once editing and illustration preparation have been completed.

Thomas R. Hester

Director 
Thomas R. Hester

\section{INTRODUCTION}

The Texas archaeological record has produced a variety of evidence of human occupation during the late Pleistocene. In 1924, chipped stone projectile points were found associated with extinct species of Bison along Lone Wolf Creek, near Colorado City. This discovery did not receive much attention at the time, yet it pre-dated by two years the Folsom finds in New Mexico--the highly-touted break-through for Pleistocene archaeology in the New World. Archaeologists (both professionals and amateurs), geologists and paleontologists were a11 to make significant discoveries of Pleistocene archaeological manifestations following the events at Lone Wolf Creek. Foremost among these scholars was E. H. Sellards, whose many accomplishments in the field of Pleistocene archaeology are summarized in his book, Early Man in America (1952). And, we cannot overlook, in the realm of amateur archaeology, the persistent efforts of Cyrus N. Ray in the Abilene area in the 1920's and 1930's.

In the two decades following the publication of Sellards' synthesis, there have been substantial advances in 1ate Pleistocene archaeology in Texas; the most productive of these have utilized a multidisciplinary approach, including, among the project personnel, zoologists, botanists, paleontologists, geologists, palynologists, and so on. Sub-areas of archaeology, such as experimental archaeology and interpretative faunal studies have also helped to provide a broad range of new ideas and concepts about late Pleistocene man in Texâs. A recent symposium held at The Museum of Texas Tech University indicated the great strides that are being made in the field of Pleistocene studies throughout North America.

\section{MAN'S ANTIQUITY IN THE NEW WORLD}

There has been a vigorous debate among New World prehistorians in recent years about the antiquity of human populations in this hemisphere. Some purported sites, such as the Calico Hills locality in California's Mojave Desert, have yielded chipped stones for which claims of from 40,000 - 100,000 years of age have been made. In the case of Calico Hills, these claims have been quite convincingly dashed by Haynes (1973). A review of most of these putative "very early" localities can be found in a paper by Krieger (1964) in which they are grouped in his "Pre-Projectile Point" stage.

*STightly revised paper presented at a symposium, "Pleistocene Climates of Texas" (E. L. Lundelius, organizer). Annual meeting, Texas Academy of Science, Texas A \& M University, March 5, 1976. 
In the past few years, a series of sites, as in the 01d Crow River locality in the Yukon, Valsequillo Reservoir, Mexico, and Ayacucho, Peru, and a series of skeletal remains from southern California, have provided better data on the possible human occupation of the New World at the 20,000 B.C. time level. The most convincing evidence yet to be found is that from Meadowcroft Rockshelter in Pennsylvania (Adovasio et al 1975). A long series of radiocarbon dates clustered at ca. 14,000 B.C. are reported.

However, the most secure evidence of widespread human presence in North America is still the Clovis complex, radiocarbon dated at around 11,000 years ago. The complex is distinguished by a number of mammoth kill-sites (and a lesser number of occupation localities), particularly in the American Southwest. Distinctive Clovis fluted points are found associated with the slaughtered animals in the ki11sites. Following Clovis in time, we see a shift in the projectile point technology and also in the kinds of animals that were being hunted. This is reflected in the Folsom complex, with its smaller fluted points, found in kill-sites associated with extinct species of Bison. Folsom occupation sites, such as Lindenmeier in Colorado (Wilmsen 1974), provide considerable insight into this early lifeway of ca. 8800 B.C. Although some of the earlier archaeological literature, and much of the popular literature, refer to these Clovis and Folsom peoples as "Big Game Hunters", there is more than substantial evidence that these populations were broadly adapted to a hunting and gathering subsistence pattern, exploiting a wide spectrum of economic resources (cf. Wheat 1971). To be sure, both the Clovis and Folsom hunters took their toll of mammoth and bison, and some, like Paul S. Martin (1973), bel ieve that they had a direct role in the extermination of certain species.

There have been a great number of papers in recent years describing the various aspects of late Pleistocene human 1 ifeways, covering such topics as diet, settlement systems, technology and trade, and I cite only a selected sample of these papers here: Johnson (1974a, b), Judge (1973), Wheat (1971), Fitting (1965), Tunne11 (1975), and a series of papers in a volume edited by Black (1974).

The terminal phases of the Pleistocene are reflected archaeologically by a great divergence in 1ithic traditions. Numerous ki11-sites (especially with the remains of now-extinct Bison species) and occupation sites are known from this period of roughly 8000-6000 B.C. Presumably during this era, human populations increased and expanded into diverse environmental contexts throughout most of the New World. Archaeologists generally refer to these terminal Pleistocene occupations in terms of the distinctive projectile point types associated with each, including Plainview, Hell Gap, the Cody Complex, Meserve, Dalton, Midland and Angostura (J. J. Hester 1975 groups these materials in his "Parallel Flaked Horizon").

The Pleistocene occupations that I have discussed in this section, 
ranging in age from Clovis times (ca. 9200 B.C.) up to the end of the Pleistocene (ca. 6000 B.C.), are labeled by most American archaeologists as "Paleo-Indian". Others have used such terms as "Early Lithic" or "Early Man". However, for the purposes of the present paper, I wit1 utilize the Paleo-Indian rubric in discussing those late Pleistocene human populations dating from ca. 9200 B.C. and thereafter.

\section{LATE PLEISTOCENE HUMAN OCCUPATION OF TEXAS}

Having provided a very brief introduction to certain problems in the study of Pleistocene populations in the New World, I would like to turn now to the Texas situation. Any remarks, observations, or speculations that are to be made about aboriginal adaptations in the late Pleistocene of Texas have to be considered in the light of our inadequate knowledge of the environments of this period. Perhaps the participants in this symposium will be able to collate much of the disparate information on Pleistocene environments in Texas; to do so would be a great boost to the interpretation of the archaeological evidence. There are, of course, some areas of the state, and some specific sites, such as Lubbock Lake (B1ack 1974), for which we have considerable environmental information. Wendorf (cf. 1970) and Wendorf and Hester (1975) have compiled an impressive amount of data on the late Pleistocene environments of the southern High Plains. $V$. M. Bryant, Jr. has carried out continuing paleoenvironmental studies in central and lower Pecos Texas (cf. Bryant 1969; Story and Bryant 1966). However, many areas remain inadequately studied--if they have been studied at a17. And, some segments of the overall environmental picture remain clouded, such as the oscillations of sea levels in the terminal Pleistocene and early Holocene, the changing drainage systems, fluctuations in rates of alluviation, chronology of terrace developments, etc. To be sure, geomorphologists and paleoenvironmentalists have worked out many of these problems in some sectors of the state, but other areas have been ignored and general summaries of available data are lacking. One example comes to mind. Bryant (1970) has studied a series of samples from late Pleistocene peat bogs in central and east Texas. The palynological data derived from these studies have led him to propose a "parkland" model for much of central and south central Texas for the late Pleistocene. On the other hand, geologists working with radiocarbon-dated caliche formations in Karnes county--not too great a distance from Bryant's peat bogs--suggest a "very dry climate of late Wisconsin" age (Eargle 1970:624), in the period from 12,000-18,000 B.C. Certainly the data need refinement through further research.

Our environmental perspective remains a fragmentary one at best. Yet against such a backdrop we have a perhaps even more fragmented archaeological picture. A few years ago, there were fewer archaeologists working in Texas and we could speak then in rather confident terms about the few known Paleo-Indian sites, their chronological placement, and their relationships to the better-studied sites and complexes in 
the Plains and the Southwest. We were plagued then, as we are now, by the fact that a number of the potentially most significant Paleo-Indian sites in Texas remain unpublished.

In the past decade, there have been a plethora of surveys and excavations in Texas and northeastern Mexico. As a result, many new Paleo-Indian sites have been discovered. In the remainder of this paper, I will attempt to mention many of the important sites, and to present my general impressions as to what these new data mean in terms of late Pleistocene aboriginal adaptations.

\section{WHAT IS THE EARLIEST EVIDENCE IN TEXAS?}

There are several localities in Texas which have been attributed to periods prior to 11,000 years ago (i.e., pre-clovis). The possible association of artifacts and fossils in the "equus beds" of southern Texas has been discounted by Hester (1971), after it was determined that the stone "artifact" was an object that had been chipped and altered by natural mechanisms. Instances such as these are fairly clear cut and easy to dispose of. Others are not. An example is the Lewisville locality, in Denton County, north Texas. Here there are large burned areas radiocarbon-dated at greater than 38,000 or 39,000 years ago. Some archaeologists (notably Krieger 1964:45) believe these to be hearths of ancient man, while other scholars (particularly Heizer and Brooks 1965) are of the opinion that they are burned pleistocene wood rat nests. The famed Malakoff "heads" of northeastern Texas were found deep in an ancient river terrace, reportedly associated with mammoth, horse, bison and camelops. Whether these are indeed examples of very ancient American art or fortuitously altered sandstone concretions is still very much in dispute. Friesenhahn Cave in southcentral Texas presents another enigmatic situation. Chipped stone pieces from zones containing late Pleistocene faura are believed by some to be artifacts (Krieger 1964:45), while studies of the materials by some Paleo-Indian specialists, such as Henry Irwin (1971:45), suggest that the specimens have been natural $1 y--$ not humanly--altered. Irwin (ibid) is also unconvinced by the purported bone artifacts from the Friesenhahn deposits. Chipped stone objects recovered by Russe11 Graham's recent work at the cave are being analyzed, and we shall soon have yet another opinion on whether or not man had anything to do with these lithics.

There are several other localities that have yielded strange 1 ithic assemblages, to which some archaeologists would attribute great age. There is Honea's (1966) "San Marcos Complex" of Central Texas, and the series of chipped stone objects reported by Carter and Hammond (1968) from the Bryan vicinity.

I do not wish to leave the impression that all of the above-mentioned localities are meaningless in terms of very early human occupation of Texas. I remain skeptical about them simply because of the lack of 
substantial evidence to the contrary; i.e., there are no definitive data from any of these localities which show convincingly that man was there. Two sites come to mind which might provide such evidence. One is Bonfire Shelter on the Rio Grande in Val Verde County. Excávations by Dibble (Dibble and Lorrain 1968) revealed a bone bed (their Bone Bed I) containing bison, proboscidians, camelops, and equus, along with possible bone-smashing tools, about a foot below Bone Bed 2, radiocarbon-dated at Ca. 8000 B.C. Bone Bed I was only briefly sampled; it may date to Clovis times, or it may be from an even earlier epoch. Alternatively, the bone bed may not even be related to human activities. At Levi Rockshelter in Travis County, Alexander has excavated a basal zone containing artifacts associated with tapir and dire wolf. The zone is not chronometrically dated, but underlies a zone radiocarbon-dated at 8050 B.C. (Alexander 1963). I have been told that Alexander has conducted additional work at Levi in recent months, and that even earlier cultural materials were found. We will have to await the publication of these findings.

I think that it is entirely possible that we shall find, here in Texas, as Adovasio, Gunn and their associates have done in Pennsylvania, evidence of Pleistocene human populations at the 14,000 B.C. time level or earlier. The evidence does not yet exist, but perhaps we shall eventually discover it in such sites as Bonfire, Levi, or the poorly known Montell Rockshelter of Uvalde County.

\section{THE PALEO-INDIAN PROBLEM}

There are numerous sites, both surface occurrences and excavated localities, in Texas that have yielded artifactual and related faunal materials dating from the late Pleistocene.

In the early part of the Paleo-Indian period, around 8000-9000 B.C., I believe we can discern two major traditions in Texas and northeastern Mexico, apparently reflecting cultural adjustments to local environments and subsistence resources. The most visible of these is the Prainsrelated Tradition. In this I would group all of the Clovis and Folsom sites known thus far in the state. Although Irwin (1971:50) indicates the extension of Plains Paleo-Indian groups into parts of Texas, he was not aware of the maximum range of these groups in the region. To date, most of the major Plains-related sites of Clovis and Folsom times are in the north-central and panhandle areas of the state. Clovis sites include Miami, in Roberts County (Sel1ards 1952), McLean, near Abilene (Bryan and Ray 1938) and, possibly, the newly discovered Rex Rodgers site in the panhandle. Folsom sites are more numerous, and include the Lipscomb site in the panhandle (Schultz 1943), the extensively-studied Lubbock Lake site (Black 1974), the Adair-Steadman site in north central Texas (Tunnel1 1975), Chispa Creek, near Van Horn (see Wormington 1957), Bonfire Shelter in Val Verde County (Dibble and Lorrain 1968), and Kincaid Rockshelter on the edge of the Edwards Plateau. Aside from these excavated sites, Clovis and Folsom points 
typologically identical to their Plains and Southwestern counterparts, have been found at excavated and surface localities in eastern, coastal, and extreme southern Texas. There is very little, if any, substantial evidence of classic Clovis or Folsom points found south of the Rio Grande. Aside from the Bonfire kill-site, we have little in the way of faunal associations with the Clovis and Folsom materials in central and southern Texas. Pleistocene bison occurred at Kincaid but not in direct association with the Folsom materials. Lundelius (1975) has noted the presence of late Pleistocene bison on the Texas coastal plain, and its absence in adjacent Mexico. Although Folsom period kil1-sites are not yet known from the coastal plain, numerous folsom points have been found. The co-occurrence of Folsom points and late Plejstocene bison in lower Texas, and the absence of both in adjacent Mexico is, to my mind, highly significant in terms of aboriginal adaptive strategies. In dealing with the earlier Clovis materials, there is also no conclusive evidence of mammoth and human artifact associations in the lower half of Texas (one probable exception is the Buckner Ranch locality which is discussed Tater). Mammoth remains are common in Plejstocene deposits, although the dating of the remains is imprecise. Clovis points have been found scattered over much of the region in which these mammoth remains occur, and perhaps eventually a ki11-site will be discovered. In the past year, geologist Raymond Suhm has excavated a paleontological locality in Kenedy County, near Kingsville. Mammoth, possible musk ox, bison and a variety of other Pleistocene fauna are al1 present. The mammoth remains have been radiocarbon-dated, according to newspaper accounts, to ca. 7500 B.C. No artifacts have been found in situ, although a crudely bifaced cobble and a bipointed biface (possibly a projectile point) were found in the backdirt of the excavations. But, also in the backdirt piles were artifacts of later periods, such as a Nolan dart point probably dating after 3500 B.C. It is, of course, completely impossible to 1 ink any of these displaced artifacts to the late Pleistocene fauna; the most interesting facet of this discovery is the apparent late survival of mammoth on the lower coastal plain.

In this same part of the early Paleo-Indian period (ca. 8000-9000 B.C.), there is substantial evidence emerging from northeastern Mexico of a distinctively different cultural tradition. These findings are the result of the work of Jeremiah F. Epstein and his students at The University of Texas at Austin. Epstein (1975) has termed this early evidence the Small Projectile Point Tradition. Although Epstein's evidence suggests this tradition was a long-lived one, there is secure information from the site of La Calzada, Nuevo Leon, that the tradition began as early as 8600 B.C. Fluted points of the Plains-related tradition are absent from the excavated sites reported by Epstein and his students, and no definite fluted specimens have been found from their wide-ranging surface surveys in northeastern Mexico. The Plains-related tradition does occur farther to the north in Mexico, particularly in Sonora (Ortiz 1974), in areas adjacent to the focus of Southwestern U.S. sites. 
Thus, there seem to be two major traditions present in the Texasnortheastern Mexico area between 8000-9000 B.C. One is the Plainsrelated fluted point tradition, apparently reflecting a lifeway found across the Plains, the Southwest and into Texas. The other, 'a smal1 point tradition, is best documented in northeastern Mexico, but with the presence of similar (though still undated) specimens in parts of lower and western Texas, it is likely that this tradition extended into Texas. At present, the borderlands along the lower Rio Grande seems to be a convenient dividing line between the two.

The problems really arise when one attempts to dea 1 with the terminal Pleistocene, or "late Paleo-Indian", archaeological remains in Texas. Perhaps because of ameliorating climatic conditions, and certainly due to the expansion of human populations into practicaliy every available ecological niche, one finds a wide diversity of cultural remains in North America at this time. In years past, Texas archaeologists attempted to fit their "late Paleo-Indian" materials into the Plains model; i.e., to make the Texas types conform with those found at ki11 and occupation sites in the Plains and Southwest. This has caused confusion, and the confusion has not been helped any by the fact that Plains archaeologists have begun to reassess their typological constructs. As more sites are dug, the less sense many of the late Paleo-Indian complexes make, and the more complex the chronological sequence becomes. The Plainview tradition is a prime example. Plainview points were first identified at a bison ki11-site in Texas. Soon most parallelsided, parallel-flaked projectile points with slightly concave bases were being dubbed Plainview. More recently, Irwin (1971) has presented data suggesting that a complex which he calls Plainview is intermediary between Clovis and Folsom. And then there is the case of Bonfire Shelter at which, in Bone Bed 2, some projectile points occur along with a single Folsom point; these other projectiles are termed Plainview by some, and Midland by others. It is getting hard to keep track of a11 the typological mutations apparentiy underway.

The terminal Pleistocene in Texas is known primarily from a number of different projectile point types, found widely scattered in surface contexts. These include Plainview, Golondrina (a form about which I will have more to say below), Midland (?), Scottsbluff, Meserve (most of which appear to be nothing more than reworked examples of other types), and Angostura. Most of these forms are widely dispersed across the state, although there are regional concentrations of some forms, such as Scottsbluff in eastern Texas and the Golondrina form in central, lower Pecos and southern Texas.

There are a number of important terminal pleistocene sites that have been excavated in Texas. The kill-sites (involving now-extinct species of Bison) include Lone Wolf Creek, Plainview, and Biedleman. Occupation sites include Levi, Devil's'Mouth, Baker Cave, Horn Shelter near Waco (this site apparentiy has earlier Paleo-Indian manifestations, but is as yet unpublished), St. Mary's Hall in San Antonio, and the Johnston- 
Heller site in Victoria County (the latter is described in a paper in the present volume). The kill-sites, primarily in northern Texas, reflect the Plains Paleo-Indian orientation towards bison kills. Farther to the south, as at Levi Rockshelter and Baker Cave, one sees a highly varied fauna, reflecting the utilization of small mammals, rodents, fish, etc., and no apparent exploitation of late Pleistocene megafauna (if indeed they were available in these more southerly areas around 7500-6000 B.C.). The occupation sites contain a variety of cultural debris reflecting a broadly adapted hunting and gathering lifeway; materials include projectile points, bifacial and unifacial cutting and scraping tools, waste debris from tool manufacture and rejuvenation, hammerstones, and some milling stones. An antler tool of late Pleistocene date has been reported from a buried locality in northeastern Texas (Slaughter and Hoover 1965:351-352).

The terminal Pleistocene in Texas appears to have seen a wide range of adaptations, reflecting the use of fairly localized environments and resources, and leading to the development of regional lithic specializations. At Levi in central Texas one sees a highly localized series or projectile points, beginning around 7500 B.C., apparently the forerunners of another localized form, the Angostura type of central Texas of ca. 5500-6000 B.C. (based on the Levi data). In southern Texas, the lower Pecos, and northeastern Mexico, there is a lithic tradition characterized by Golondrina points* and bifacial Clear Fork tools. The only radiocarbon evidence comes from Devil's Mouth (Sorrow 1968) and Baker Cave (Word and Douglas 1970) and suggests a date for the Golondrina form of ca. 7000 B.C. Major sites of the Golondrina tradition, in addition to Devil's Mouth (Johnson 1964) and Baker Cave, include San Isidro, Nuevo Leon (Epstein 1969), the San Miguel Creek sites (Hester 1968), the Johnston-Heller site (Birmingham and Hester 1976) and the partially-excavated St. Mary's Hall site, San Antonio (Hester notes).

One Texas site at which a variety of Paleo-Indian materials are represented, in association with late Pleistocene fauna, is Buckner Ranch or the Berclair terrace locality in Bee County. The site has long been ignored either because some archaeologists believed it to be of mixed context (secondary deposition) or because they were perplexed by the apparent co-occurrence of several projectile point forms, including Clovis, Folsom or Midland, Scottsbluff, Angostura and stemmed forms of purported Archaic affinity. In reexamining the published and unpublished data, I believe that the locality served as a campsite for a succession of Paleo-Indian groups. In addition to the projectile points and fauna, there is an abundance of waste flakes from tool manufacture, there are tools (such as the Clear Fork form) and there are such oddities as burned mud dauber nests, probably not a food resource (larvae) but which may provide data on local environmental conditions

\footnotetext{
*A full-scale computer-aided attribute analysis of Plainview and Golondrina points by T.C. Kelly (The University of Texas at San Antonio) confirms that these two forms are typologically discrete.
} 
(cf. Freimuth and La Berge 1976). Sellards' (1940) excavation techniques were adequate and his recording methods, at least from the horizontal perspective, were excellent. I think the confusion has arisen from the vertical control excercised in the excavations. In the Lower Horizon at Site \#1, the above mentioned materials spanned a vertical extent from 13 to 18 feet below the surface; i.e., a fivefoot thick zone. Depths were recorded for the points, but this was only in relation to surface datums, and did not take into consideration the possible undulations of obscure stratigraphic relationships. What I see in the Buckner Ranch case is a preferred campsite to which a succession of $\mathrm{Paleo-Indian}$ hunters and gatherers returned to over a period of perhaps 3000 years. The most interesting thing to me about this settlement pattern is that it is of the same order as those of the following Holocene hunters and gatherers in that section of Texas. Furthermore, the occurrence of two large side notched points in the Lower Horizon is not the problem it used to be. Recent archaeological work in Texas has shown that such points extend back into late PaleoIndian and immediate post-Pleistocene times (Sorrow, Shafer and Ross 1967), and side-notched points have been found elsewhere in clear association with a kill-site of late Pleistocene bison (Agogino and Frankforter 1960).

\section{CONCLUDING OBSERVATIONS}

The adaptive strategies of Pleistocene human occupations in Texas can only be dimly discerned. We still have a very meagre environmental perspective and we have a changing theoretical base in which we are reevaluating our ideas about the antiquity and nature of these pleistocene populations. The question of man in Texas prior to the late Pleistocene Clovis complex is still an open issue, although I suspect that data confirming an earlier presence will be found. By 8000-9000 B.C., Texas and adjacent northeastern Mexico were populated by groups, as reflected in two major 1ithic traditions, the Plains-related tradition (Clovis, Folsom) and the Small Point Tradition, the latter primarily in Mexico and the borderlands areas. This assessment is undoubtedly too simplistic and will certainly be discarded as better data are obtained. Is the plains tradition in much of Texas indicative of the availability of the kinds of resources (particularly bison) found elsewhere in the Plains and in the Southwest at this time? If so, the presence of the Plains fluted points are suggestive of nothing more than a widespread hunting technology linked to a particular exploitative pattern. In a similar vein, the apparently unrelated Small Point Tradition defined by Epstein must reflect a different hunting technology in the area where it occurs. We might well ask if this tradition has a southern link, perhaps with the leaf-shaped point tradition as noted in the Valley of Mexico mammoth kill sites. Beyond contrasting the hunting or subsistence adaptations of the two traditions, I think we can say little else of significance at this time.

By the terminal Pleistocene, human populations had considerably increased in Texas. It would appear that the bison herds were restricted primarily to the north, and the regional vagaries of environment led to the 
development of localized cultural patterns, reflected archaeologically in the chipped stone technology, settlement patterns and economic modes. These aspects of terminal Pleistocene culture differ little from the succeeding thousands of years of hunting and gathering populations found over much of Texas.

\section{BIBLIOGRAPHY}

Adovasio, J. M., J. D. Gunn, J. Donahue, and R. Stuckenrath

1975 Excavations at Meadowcroft Rockshelter, 1973-1974:

A Progress Report. Pennsylvania Archaeologist 4(3): $1-30$.

Agogino, G. A. and W. D. Frankforter

1960 A Paleo-Indian Bison-Ki11 in Northwestern Iowa. American Antiquity 25(3): 474-415.

Alexander, H. L.

1963 The Levi Site: A Paleo-Indian Campsite in Central Texas. American Antiquity 28(4): 510-528.

Birmingham, W. W. and T. R. Hester

1976 Late Pleistocene Archaeological Remains from the JohnstonHeller Site, Texas Coastal Plain. This volume.

Black, C. C., ed.

1974 History and Prehistory of the Lubbock Lake Site. The Museum Journal XV. West Texas Museum Association, Texas Tech University.

Bryan, K. and C. N. Ray

1938 Long Channelled Point Found in AlTuvium Beside Bones of Elephas Columbi. Bulletin of the Texas Archeological and Paleontological Society 10: 263-268.

Bryant, V. M., Jr.

1969 Late Fullglacial and Postglacial Pollen Analys is of Texas Sediments. Ph.D. dissertation, The University of Texas at Austin.

1970 General Comment. University of Texas at Austin Radiocarbon Dates VIII. Radiocarbon 12(2): 625. 
Carter, G. F. and P. Hammond

1968 A Lithic Industry from Central Texas. Anthropological Journal of Canada 6(4): 2-6.

Dibble, D. S.

1970 On the Significance of Additional Radiocarbon Dates From Bonfire Shelter, Texas. Plains Anthropologist 15(5): $257-254$.

Dibble, D. S. and D. Lorrain

1968 Bonfire Shelter: A Stratified Bison Kill Site, Val Verde County, Texas. Miscellaneous Papers of the Texas Memorial Museum 1.

Eargle, D. H.

1970 General Comment. University of Texas at Austin Radiocarbon Dates VIII. Radiocarbon 12(2): 624.

Epstein, J. F.

1969 The San Isidro Site, An Earry Man Campsite in Nuevo Leon, Mexico. Anthropological Series, The University of Texas at Austin 7.

1975 Some Reflections on the Nature of the Northeast Mexico Lithic Tradition and the Problem of its Origin. Paper presented at the Conference on the Prehistory of Northeastern Mexico, Monterrey, N.L., Mexico.

Fitting, J. E.

1965 Observations on Paleo-Indian Adaptive and Settlement Patterns. Michigan Archaeologist 11(3-4): 103-109.

Freimuth, G. and W. LaBerge

1976 Dating and Environmental Reconstruction from Prehistoric Mud-Dauber Nests: Some Possibilities. Plains Anthropologist 21(72): 111-114.

Haynes, C. V.

1973 The Calico Site: Artifacts or Geofacts? Science 181: 305-310.

Heizer, R. F. and R. Brooks

1965 Lewisville - Ancient Campsite or Wood Rat Houses?

Southwestern Journal of Anthropology 21: 155-165. 
Hester, J. J.

1975 Paleoarchaeology of the Llano Estacado. In: Late Pleistocene Environments of the Southern High Plains. ( $F$. Wendorf and J. Jester, eds.), pp. 247-256. Publications of the Fort Burgwin Research Center 9.

Hester, T. R.

1968 Paleo-Indian Artifacts from Sites Along San Miguel Creek: Atascosa, Frio, and McMu11en Counties, Texas. Bulletin of the Texas Archeological Society 39: 147-161.

1971 An "Eolith" from Lower Pleistocene Deposits of Southern Texas. Bulletin of the Texas Archeological Society 42: 367-371.

Honea, K. M.

1966 Prehistoric Flaking Technologies in Texas. International Congress of Prehistoric and Protohistoric Sciences, 6th (1962), Atti 3: 260-267.

Irwin, H. T.

1971 Developments in Early Man Studies in Western North America, 1960-1970. Arctic Anthropology 8(2): 42-67.

Johnson, E.

1974a Paleoindian Bison Procurement on the Llano Estacado. Bison symposium paper presented at the 32nd annual meeting of the Plains Conference, Laramie, Wyoming.

1974b Avifauna of the Lubbock Lake Site. Paper presented at the 39th annual meeting of the Society for American Archaeology, Washington, D. C.

Johnson, L., Jr.

1964 The Devi7's Mouth Site, A Stratified Campsite at Amistad Reservoir. Department of Anthropology, University of Texas, Archaeology Series 6.

Judge, W. J.

1973 Paleoindian Occupation of the Central Rio Grande Valley in New Mexico. University of New Mexico Press, Albuquerque.

Krieger, A. D.

1964 Early Man in the New World. In: Prehistoric Man in the New World (J. Jennings and E. Norbeck, eds.), pp. 23-84. Rice University Press, Houston. 
Lundelius, E. L.

1975 Late Pleistocene and Holocene Mammals from Northern Mexico and Their Implications for Archeological Research. Paper presented at the Conference on the Prehistory of Northeastern Mexico, Monterrey, N.L., Mexico.

Martin, P. S.

1973 The Discovery of America. Science 1979(4077): 969-974.

Ortiz, M. R.

1974 Distribución de Artefactos Clovis en Sonora. Boletin, INAH, Epoca II, Abri7-Junio: 25-32.

Schultz, C. B.

1943 Some Artifact Sites of Early Man in the Great Plains and Adjacent Areas. American Antiquity 8(3): 242-295.

Sellards, E. H.

1940 Pleistocene Artifacts and Associated Fossils From Bee County, Texas. Bulletin of the Geological Society of America 51: 1627-1658.

1952 Early Man in America. University of Texas Press, Austin.

Slaughter, B. H. and B. R. Hoover

1965 An Antler Artifact from the Late Pleistocene of Northeast Texas. American Antiquity 30(3): 351-352.

Sorrow, W. M.

1968 The Devil's Mouth Site: The Third Season - 1967. Papers, Texas Archeological Salvage Project 14.

Sorrow, W. M., H. J. Shafer, and R. E. Ross

1967 Excavations at Stillhouse Hollow Reservoir. Papers of the Texas Archeological Salvage Project 11.

Story, D. A. and V. M. Bryant, Jr.

1966 A Preliminary Study of the Paleoecology of the Amistad Reservoir Area. Report submitted to the National Science Foundation. 
Tunne11, C.

1975 Fluted Projectile Point Production as Revealed by Lithic Specimens from the Adair-Steadman Site in Northwest Texas. Texas Historical Commission, Office of the State Archeologist, Special Report 18.

Wendorf, $F$.

1970 The Lubbock Subpluvial. Pleistocene and Recent Environments of the Central Great Plains, Department of Geology, University of Kansas, Special Publication 3: 23-35.

Wendorf, F. and J. J. Hester, eds.

1975 Late Pleistocene Environments of the Southern High plains. Publication of the Fort Burgwin Research Center 9.

Wheat, J. B.

1971 Lifeways of Early Man in North America. Arctic Anthropology 8(2): 22-31.

Wilmsen, E. N.

1974 Lindenmeier: A Pleistocene Hunting Society. Harper and Row, New York.

Word, J. H. and C. L. Douglas

1970 Excavations at Baker Cave, Val Verde County, Texas. Bulletin of the Texas Memorial Museum 16.

Wormington, H. M.

1957 Ancient Man in North America. Denver Museum of Natura1 History: 


\title{
LATE PLEISTOCENE ARCHAEOLOGICAL REMAINS
}

\section{FROM THE JOHNSTON-HELLER SITE, TEXAS COASTAL PLAIN*}

\author{
William W. Birmingham and Thomas R. Hester
}

\section{INTRODUCTION}

With this brief preliminary paper, we would like to document a series of artifacts which represent early occupations at an archaeological site on the Texas coastal plain. The locality, designated the JohnstonHeller site (41 VT 15), is situated on the west side of Rocky Creek just above its confluence with the Guadalupe River, near the city of Victoria, approximately 40 miles from the Gulf of Mexico (Figs. 1 and 2). Although cultivation and erosion have exposed some archaeological materials, most of the site lies buried in deep alluvial soils (the Trinity-Catalpa series). The site is situated in a riverine environment, flanked on both sides of the river by a fairly broad and flat floodplain (Fig. 2).

Test excavations by Birmingham (1966) and other amateur archaeologists from the Victoria area, have indicated the presence of a Late Prehistoric occupation just below the present site surface. Underlying this are the mixed remains of concentrated Archaic habitations. No clear-cut sequence for these Archaic materials can be discerned, although numerous temporally-diagnostic dart point types have been found, including Pedernales, Castroville, Ensor, Bulverde, Marcos, and Lange (for type definitions, see Suhm, Krieger, and Jelks 1954). The tests extended to a depth of 40 inches, where a Pedernales point and a Plainview point were found.

However, in another section of the site, a gully has cut through the alluvium to a depth of about 25 feet. At a depth of four feet, a mano and metate were found exposed in the gul7y wa71. The metate was upside down, covering the mano. Both artifacts are made of sandstone (the metate is $39 \mathrm{~cm}$ long and $27 \mathrm{~cm}$ wide, and the mano is $13 \mathrm{~cm}$ long and $12 \mathrm{~cm}$ wide). Also in this area, an i11-defined zone of cultural debris has been observed in a tan soil unit between eight and twelve feet below the surface. Several Clear Fork tools (triangular bifaces with

- a scooped-out bit or working edge) have been collected in situ from this zone (for example, Fig. 7,b). In the floor of the gully, immediately below this zone, a number of projectile points and Clear Fork tools have been found (Figs. 3 and 4 ). They include three weakshouldered lanceolate specimens, two points of the Plainview type, six of the Golondrina form, and a fluted point. We would like to emphasize that none of these points have as yet been found in place in the deeplyburied cultural zone; however, some specimens ( $c f$. Fig. 8,a) have been found in blocks of soil which have fallen from the wa11, and which can be matched with the soil of the deeply buried unit.

\footnotetext{
*An earlier version of this paper has been circulated in photocopy form under the title "Postulated Early Occupations at the Johnston Site, Texas Coastal Plain".
} 


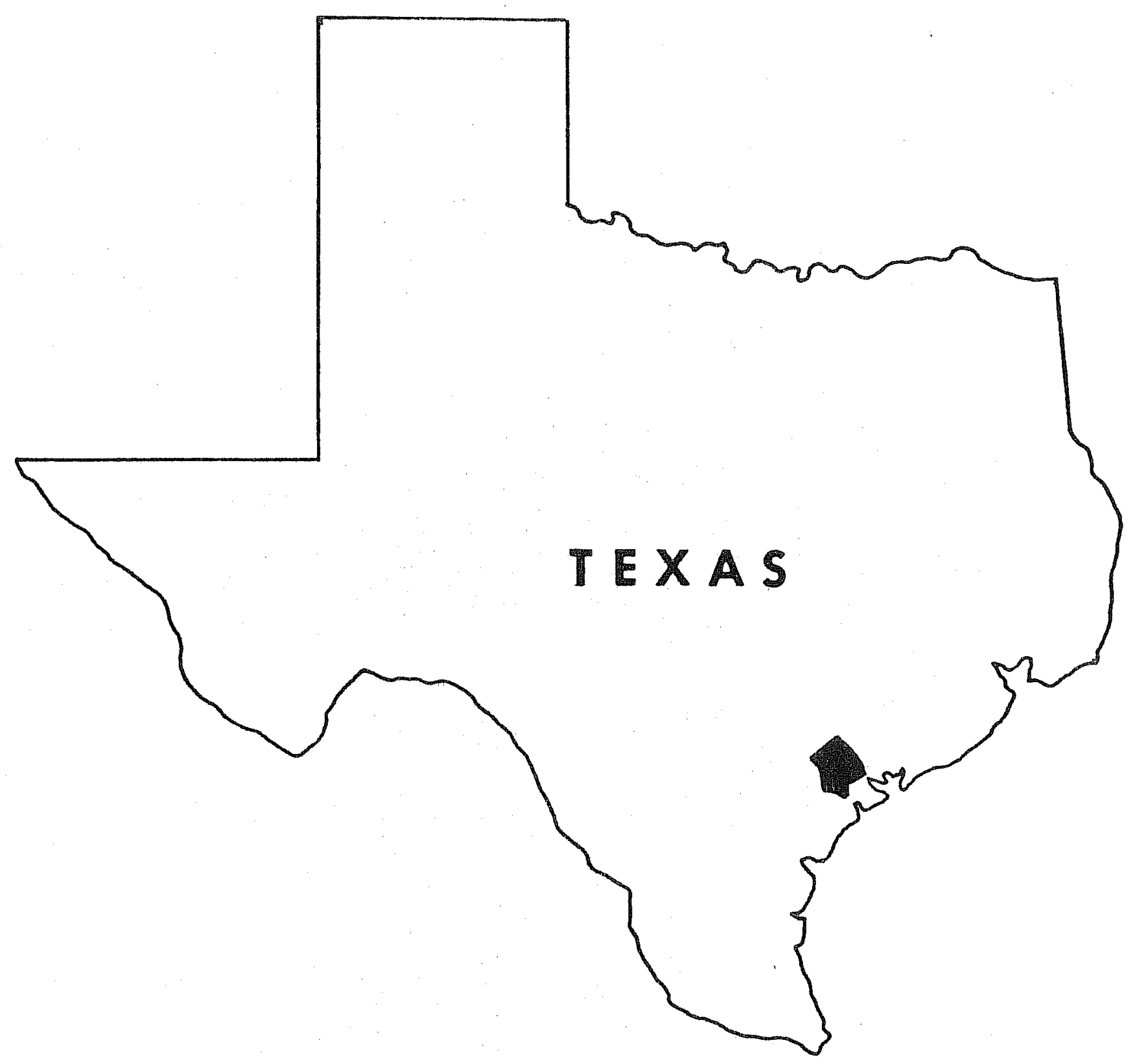

Figure 1. Location of Victoria County on the Texas Coastal Plain. 
Figure 1. Location of the Johnston-Heller Site (41VT15), Victoria County, Texas.

PAGE 17 REDACTED 
THE ARTIFACTS

Clear Fork Tools

Thirty-seven Clear Fork tools (cf. Ray 1941) have been recovered from the deep gully area at the Johnston-Heller site (see Figs. 5 and 6). As noted above, several have been found in situ in the gully walls, particularly in the south wall exposure. One specimen, however, was recently found protruding from the north wall at a depth of eight feet. Most are triangular to subtriangular in outline, nine are lanceolate (with parallel, slightly convex lateral edges), four are rectangular, two are ovate, and another has been reworked. Three specimens are fragmentary, lacking the proximal ends. A17 are bifacially-chipped, with beveled (occasionally "scooped out") bits or working edges. These specimens have not yet been examined for evidence of use-wear. However, microwear studies by Hester, Gilbow, and Albee (1973) suggest that similar implements from southern Texas may have functioned as woodworking tools. The dimensions of the Clear Fork series are summarized in Tabie 1.

Six other chipped stone tools have been found (Fig. 6,d,e; Fig. 7,c,d). One is ovate in outline, pointed at one end, and plano-convex in cross section. It exhibits trimming or retouch along one edge, and was probably used as a scraper (Fig. 7,d). This specimen was found on the gully floor in situ in a block of tan soil derived from the gully wa11. A paral1elsided biface, rounded at both ends (Fig. 7,C), was discovered in the gully wal1 12 feet below the surface. There are also two ovate bifaces (Fig. $6, d, e)$, one of which has a steeply-beveled working edge. Two elongated bifaces, often termed Guadalupe adzes or gouges (cf. Hester and Kohnitz 1975), were collected from the gully floor. Similar specimens occur commonly in the immediate region, and apparently date from late Pleistocene or early Holocene times (ibid). The two examples from the Johnston-Heller site have long, parallel-edged outlines, and are plano-convex in longitudinal cross section. The proximal ends are rounded, while the distal ends are obliquely truncated (a distinctive attribute of this tool form), forming angles of $55^{\circ}$ and $75^{\circ}$ with the dorsal (convex) surface. It is presumed that these truncated ends were used in gouging or scraping activities. The dimensions of these six artifacts are given in Table 2.

Projectile Points

Four of the projectile points are lanceolate in outline, with weak shoulders, and have smoothed lateral edges from the shoulders to the base (Fig. 4,a-d). This projectile point form has been found at other sites in the Guadalupe River drainage, and somewhat similar specimens have been reported from sites in Blanco County (Orchard and Campbe11 1954: Fig. 2), and from the Strohacker site, Kerr County (Sollberger and Hester 1972).

There are two projectile points from the Johnston-Heller site which conform to the Plainview type as defined by Suhm, Krieger, and Jelks $(1954: 472)$. One specimen (Fig. 3,b, $b^{\prime}$ ) has an impact flute at the 
distal tip, and some reworking of this tip is also evident. Neat parallel flakes characterize both faces of the body. The second specimen is of tan chert and exhibits both parallel and random flake scars (see Fig. 8,a). Like the first specimen, it has dulled lateral edges. The distal half of the specimen is alternately beveled along the right edge.

Six specimens (Figs. 3 and 8) are of the Golondrina type (cf. Kelly 1976), a form initially described by Johnson (1964) as a variant of Plainview. They have deeply concave bases, the edges of which are recurved on five examples. Parallel flaking is evident on two of the specimens (Fig. $3, b_{,} b^{\prime} ;$ e, $e^{\prime}$ ). Burin-like facets occur on two examples (Fig. $\left.3, a, a^{\prime} ; d, d^{\prime}\right)$, but it is not clear if these are intentional or result from impact (cf. Epstein 1963:194). The specimen shown in Fig. $8, \mathrm{~b}$, is alternately beveled on the right lateral edge. Two of the Golondrina points (Figs. 8 b,c) were found on the gutiy floor but were in situ in blocks of tan soil derived from the south gully wa11. These two specimens, and a Clear Fork tool, occurred within an area $40 \mathrm{~cm}$ in length. Dimensions of these and other projectile points are given in Table 3. All points in the Golondrina series show extensive lateral edge smoothing.

A fluted point in the collection (Fig. 7,a, $\mathrm{a}^{\prime}$ ) appears to fall within the range of the Clovis type. It is fragmentary (the distal tip has been snapped off), lanceolate in outline, and has a concave base, one corner of which is broken. On one face (Fig. 7,a), there is a large channel flake scar, $33 \mathrm{~mm}$ in length and $15 \mathrm{~mm}$ in maximum width. Short parallel flake scars flank the channel flake. On the opposite face, the flute is shorter and more narrow, $21 \mathrm{~mm}$ long and $10 \mathrm{~mm}$ wide. Flake scars on the remainder of this face are short and parallel, al though there are some 7 arge, oblique scars near the distal end. The lateral edges are dulled. Data on other Clovis specimens from the southern Texas region have been presented by Hester $(1966,1971,1974)$.

\section{DISCUSSION}

We have already pointed out that we cannot unequivocally link the projectile points just described to the deeply-buried cultural zone at the Johnston-Heller site. Similarly, we are not absolutely sure of the relationship between the projectile points and the tools which have been found in situ in that zone. We are hampered in our evaluation of these materials in that discrete Paleo-Indian components have not been recognized in southern Texas. Numerous Plainview and Golondrina points have been found in surface contexts in the south Texas region (cf. Hester 1968). More important7y, in adjacent northeastern Mexico, J. F. Epstein (1969) has reported both Plainview and Golondrina specimens from the San Isidro site, where they co-occurred with Clear Fork tools quite similar to the ones found at the Johnston-Heller site. Given the associations reported by Epstein, arid the manner in which the Plainview and Golondrina points and the Clear Fork tools have been found at the Johnston-Heller site (the gouges sometimes in situ, with Plainview and Golondrina points and other Clear Fork tools on the gully floor below the exposed zone), 
it is our hypothes is that these materials are associated at JohnstonHeller and represent early components at the site. It is possible that the lanceolate, weak-shouldered points are also traits of components. A still earlier occupation at Johnston-Heller appears to be represented by the Clovis point.

The dating of these hypothesized early manifestations at Johnston-Heller is difficult. The Clovis type has been radiocarbon-dated at a number of sites at ca. 9200 B.C. (cf. Haynes 1971). However, we have no radiocarbon determinations for fluted points on the Texas coastal plain. The Plainview type is a characteristic form in the latter part of the PaleoIndian period (Irwin 1971). The Golondrina form is more common in southern Texas and on the coastal plain. At the Devil's Mouth and Baker Cave sites in Trans-Pecos Texas, this type has been found in

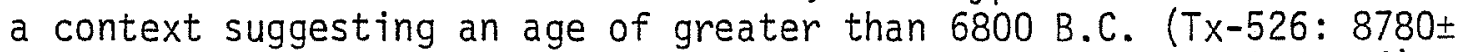
310 B.P.; Sorrow 1968; Epstein 1969:124; Word and Douglas 1970:34). The Clear Fork tool form apparently has a wide temporal span in southern Texas (Hester, White, and white 1969), although Epstein (1969:42) firmly bel ieves that these tools originated in terminal Pleistocene times.* There is evidence from the Granberg II site in San Antonio that large unifacial variants of Clear Fork occur in Early Archaic and/or Pre-Archaic times (Hester and Kohnitz 1975). We can only speculate at this juncture that the hypothesized early occupations at the Johnston-Heller site date within the late Pleistocene, perhaps 8,000-11,000 years ago. There is abundant evidence of other Paleo-Indian occupation in the Victoria County area of the Texas coastal plain. At the nearby Miller site (41 VT 5), situated on the edge of the Guadalupe River floodplain, several Clear Fork tools, Angostura-like points, a Golondrina point, and a reworked Plainview point have been found. At the J-2 Ranch site (41VT 6), in northeast Victoria County, E. H. Schmied in has collected numerous Paleo-Indian points, including Plainview, Golondrina, lanceolate points resembling Angostura and Agate Basin, and Scottsbluff points (Hester and Hi11 1971).

The validity of our hypothesized Paleo-Indian habitations at the JohnstonHeller site can be tested in at least two ways. We can continue to watch the eroding face of the deeply-buried zone, hoping to locate projectile points and other tools in place. As a more suitable alternative, controlled excavations could fully explore the context of this deep zone, as well as examine the nature (and sequence) of the cultural materials overlying it. This latter approach would hopefully provide us with chronological information now sorely lacking in this region.

*A bifacial Clear Fork specimen very similar to some examples from the Johnston-Heller site was recently found in the Golondrina stratum at Baker Cave (Hester, field notes). 


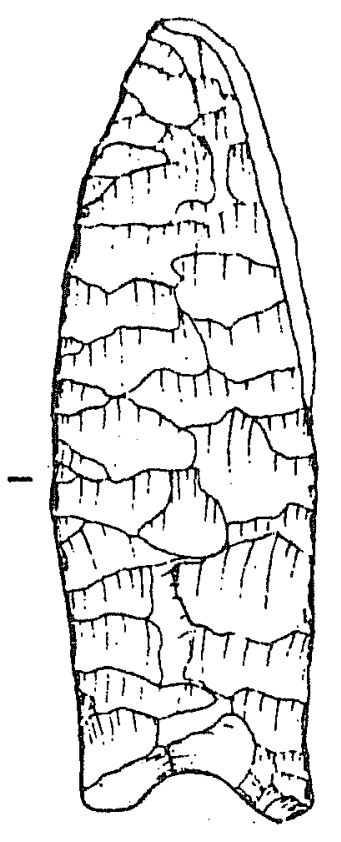

a

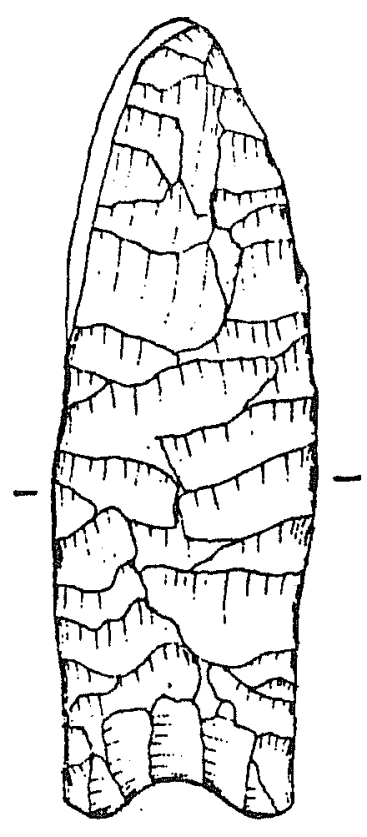

$a^{\prime}$

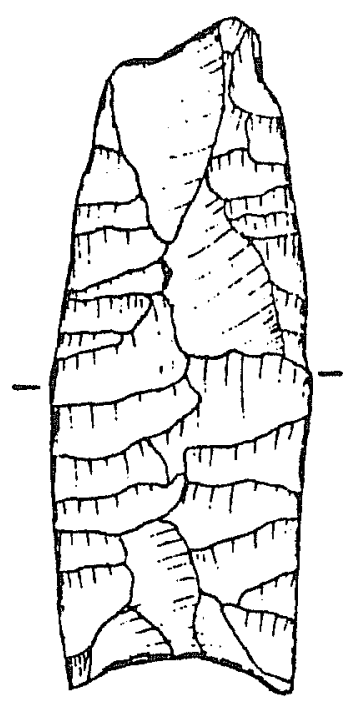

b

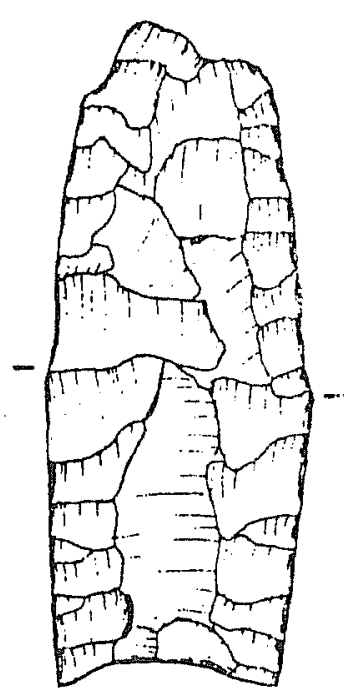

$b^{\prime}$

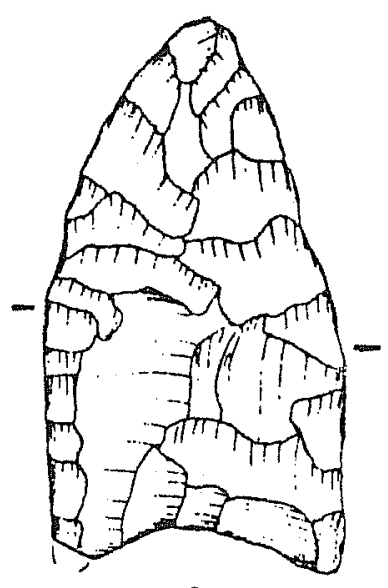

c

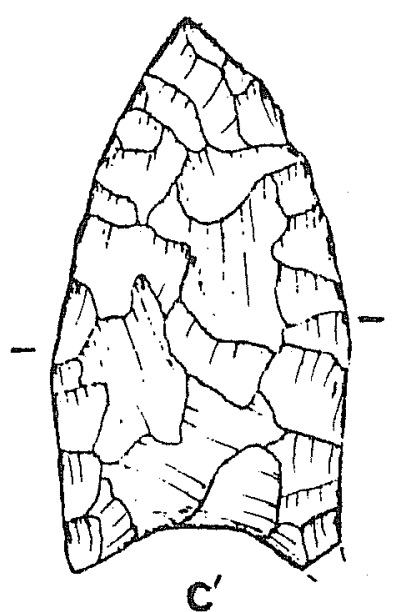

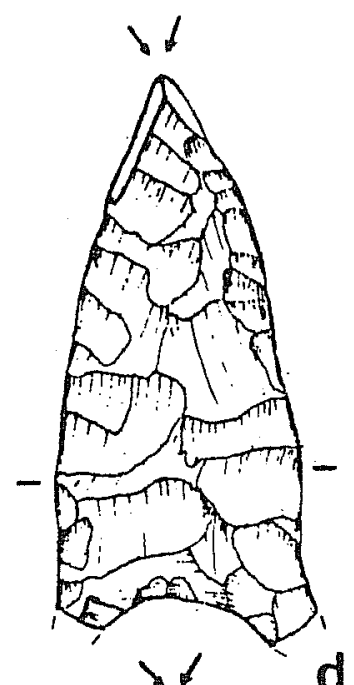

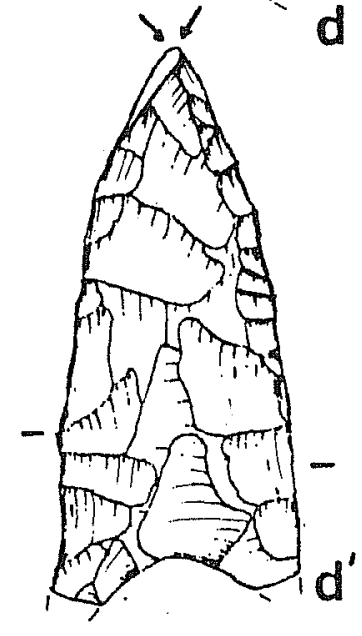

50

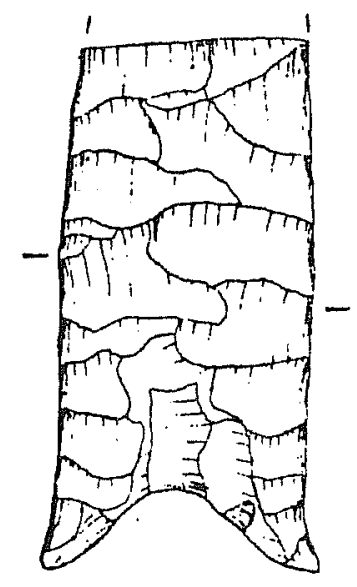

e

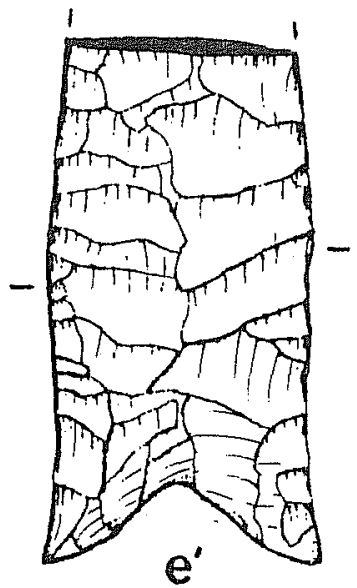

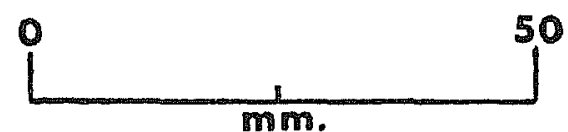

21

$m \mathrm{~m}$.

Figure 3. Projectile Points from the Johnston-Heller Site, Victoria County, Texas. a,a; c-e; Golondrina series; b,b' Plainview series. Horizontal 1 ines indicate extent of lateral edge smoothing. Note burin facets on $d, d !$. 
Figure 4. Projectile Points from the Johnston-Heller Site, Victoria County. Texas. a-d', Tanceolate, weakshouldered series. Horizontal lines indicate extent of lateral edge smoothing. Note burin facet on $b, b$ '. 


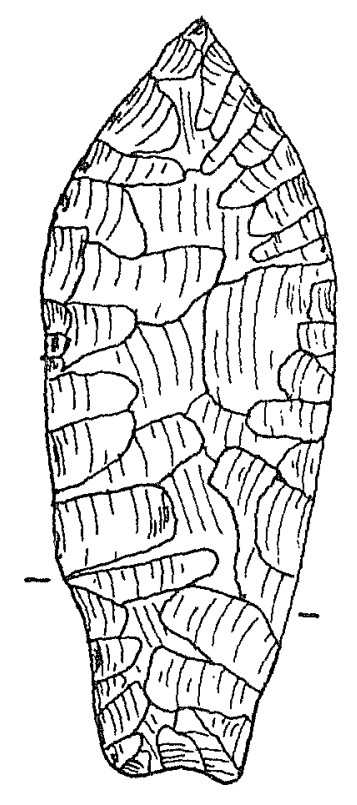

a

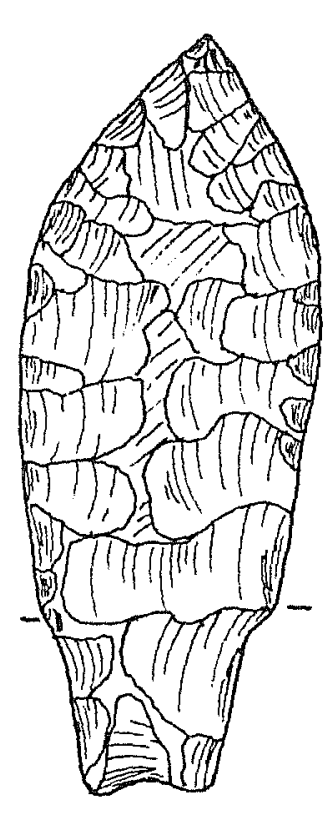

$a^{\prime}$

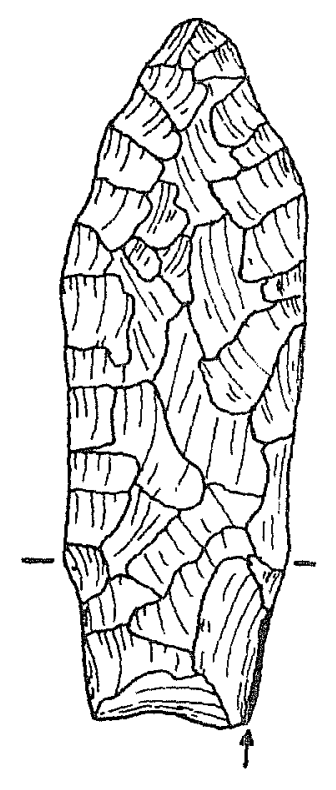

b

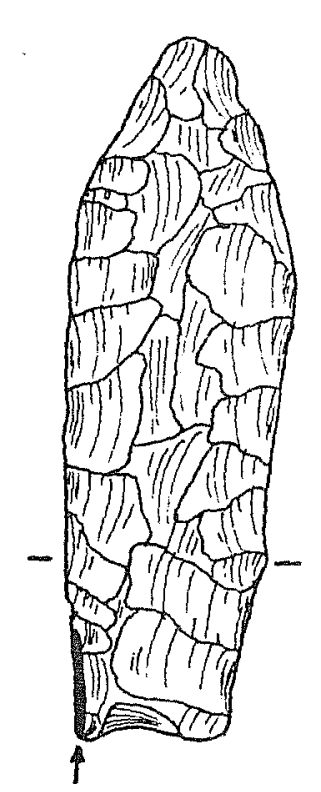

$b^{\prime}$
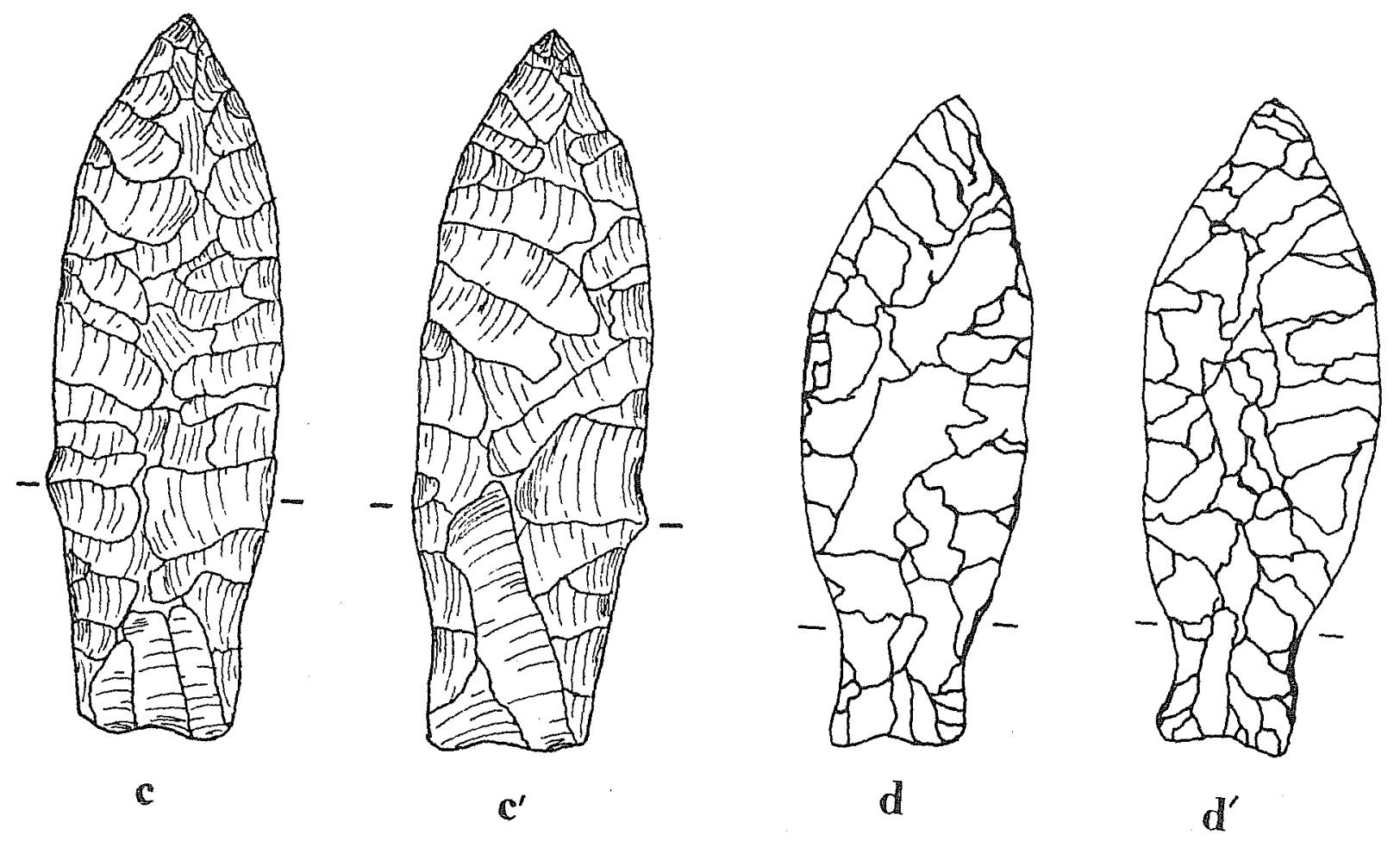

。 

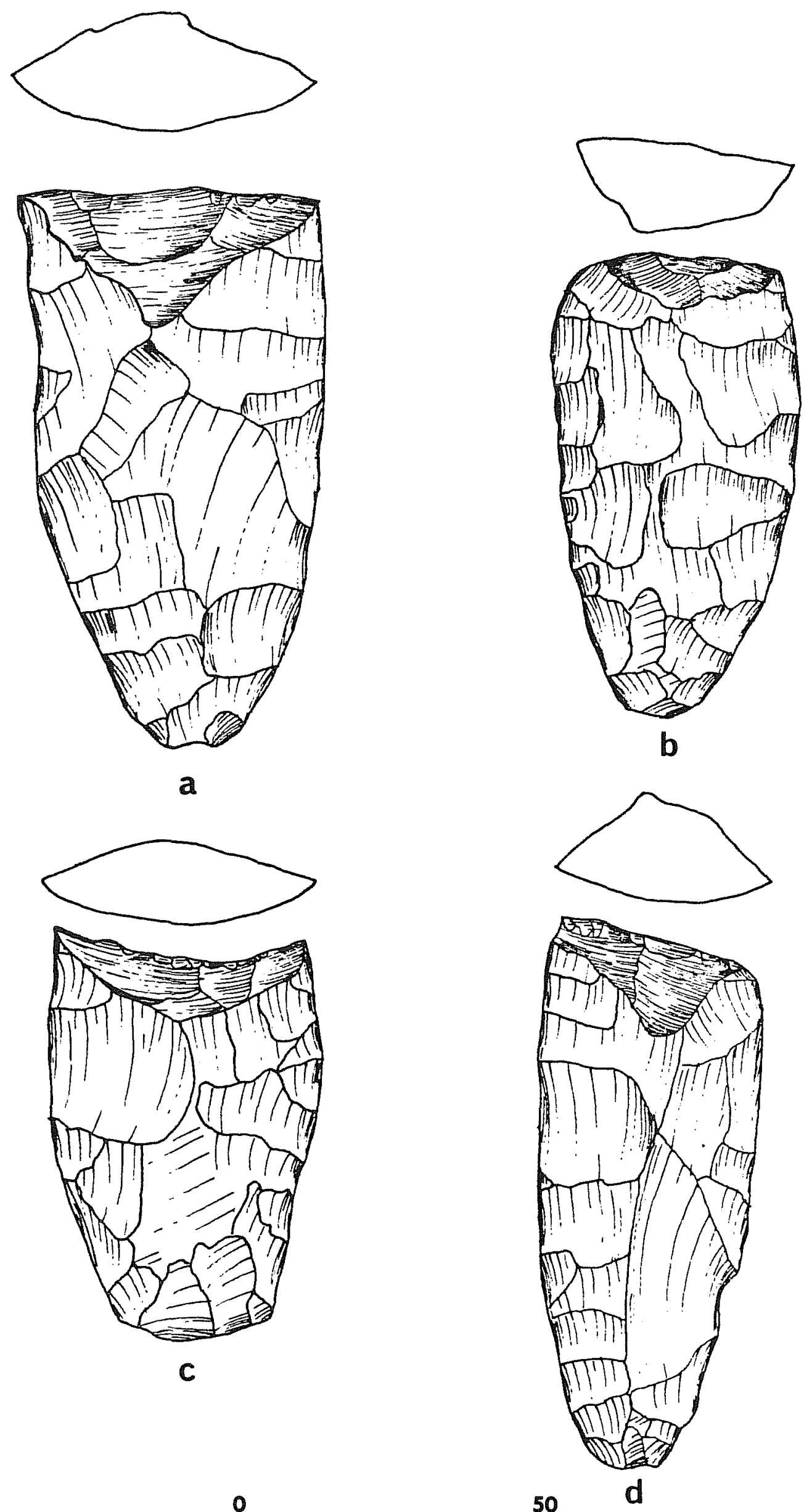

Figure 5. Clear Fork Tools from the Johnston-Heller Site, Victoria County, Texas. Cross sections of bit ends are shown. 

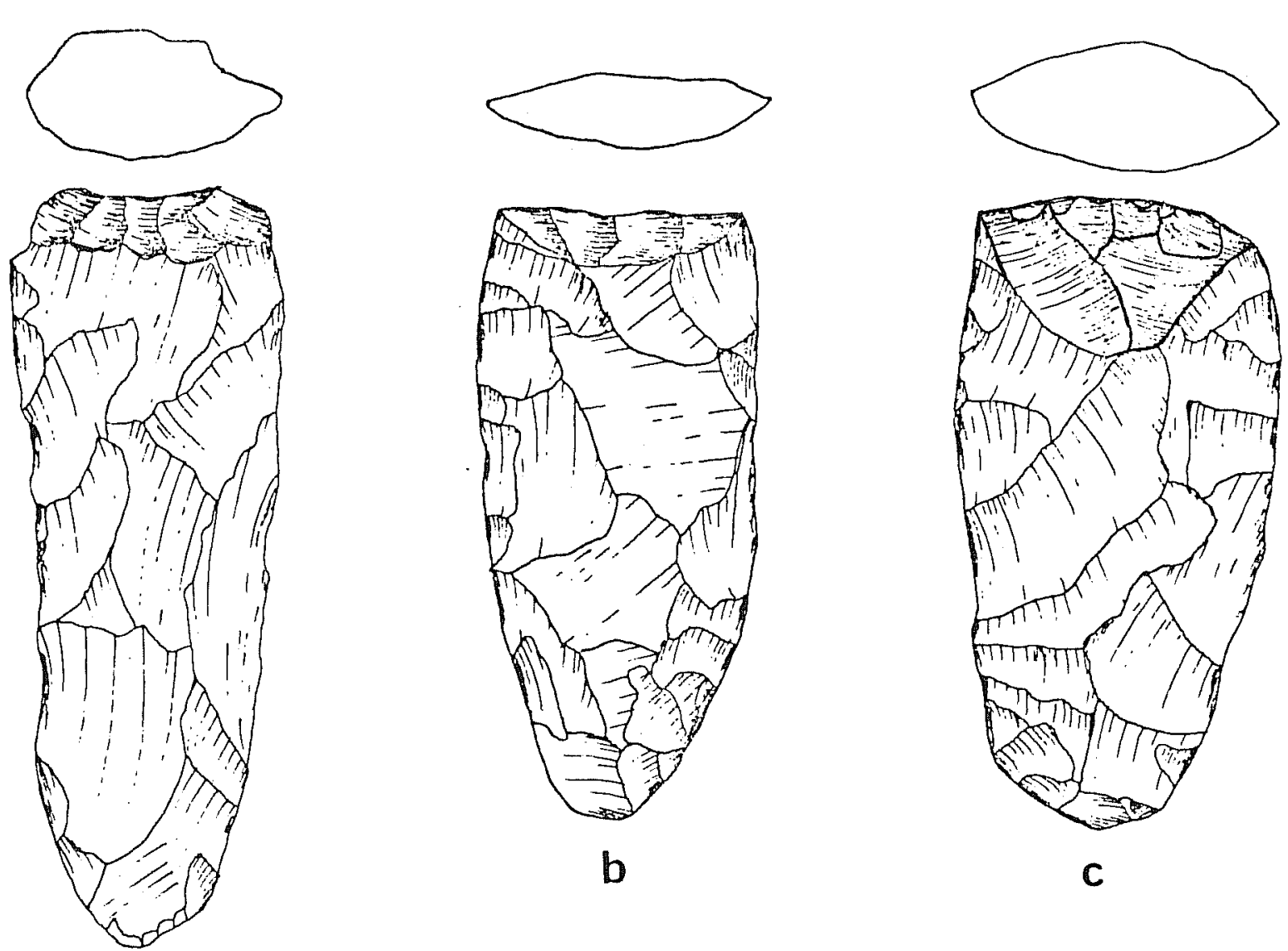

a
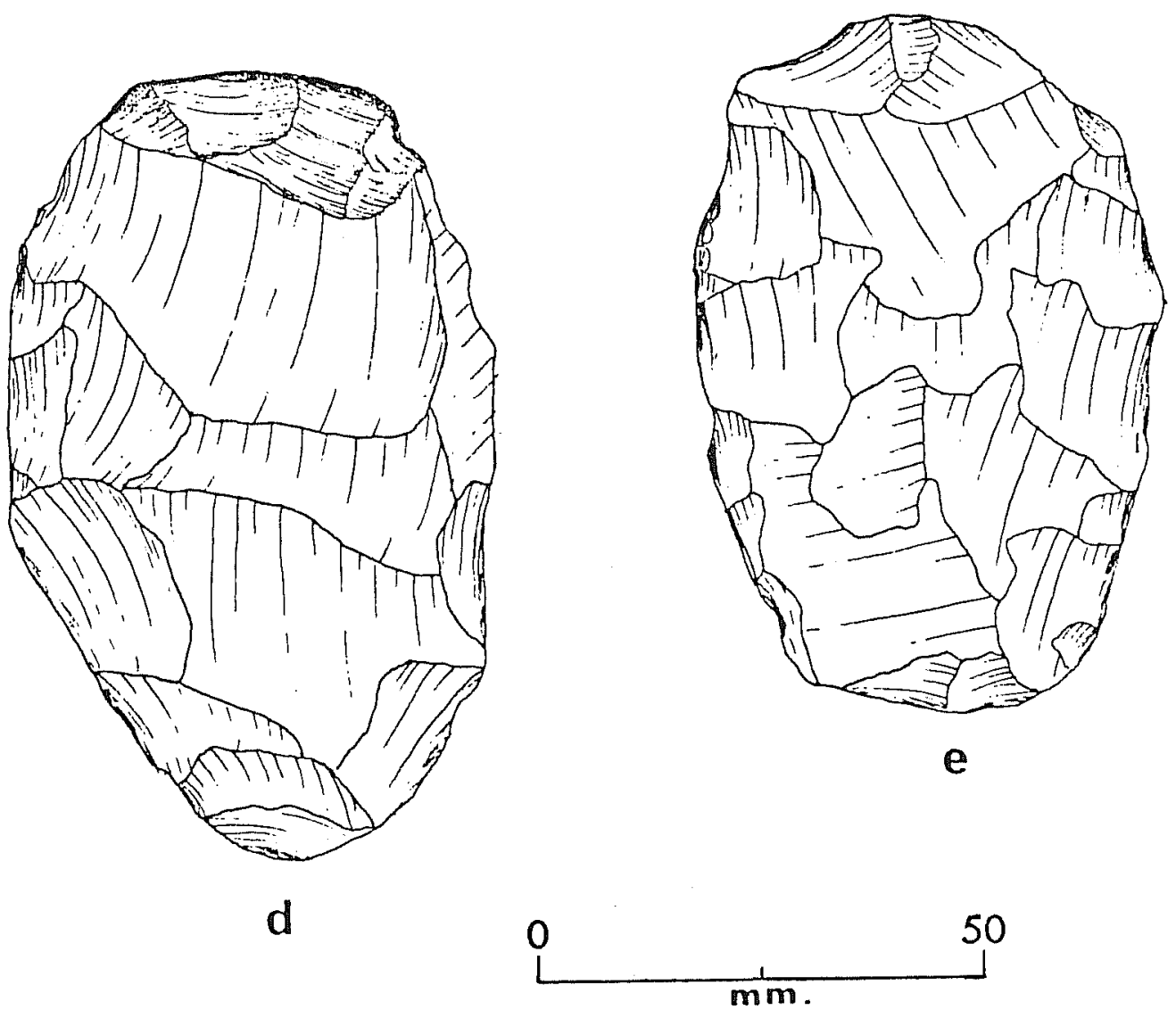

Figure 6. Chipped Stone Artifacts from the Johnston-Heller Site, Victoria County, Texas. a-c, Clear Fork tools (cross sections of bit ends are shown); $\mathrm{d}, \mathrm{e}$, ovate bifaces. 
Figure 7. Chipped Stone Artifacts from the JohnstonHeller Site, Victoria County, Texas. a, a', Clovis fluted point; b, Clear Fork tool (cross section of bit end is shown); $c$, parallel-sided biface; $d$, ovate uniface (longitudinal cross section is shown). Horizontal 1 ines indicate extent of lateral edge smoothing on $a, a^{\prime}$. 

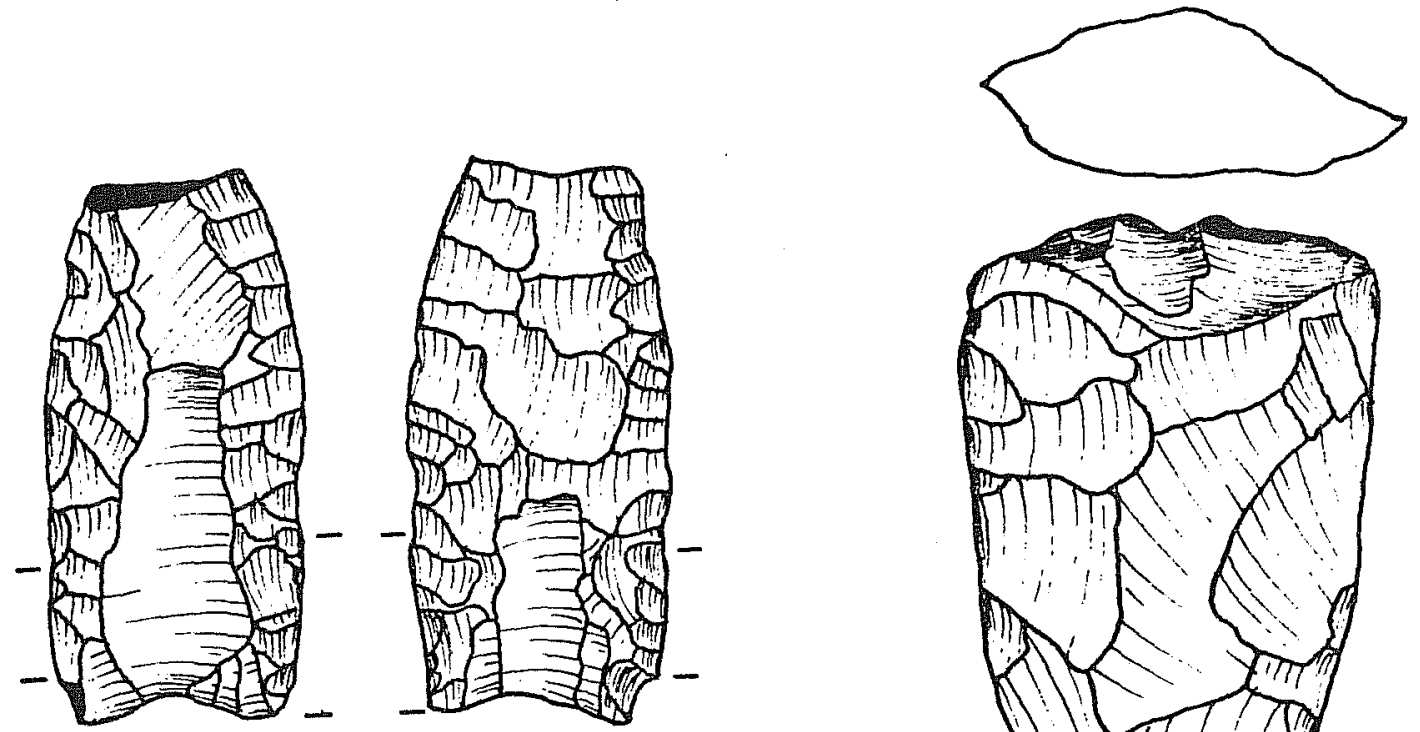

a

$a^{\prime}$

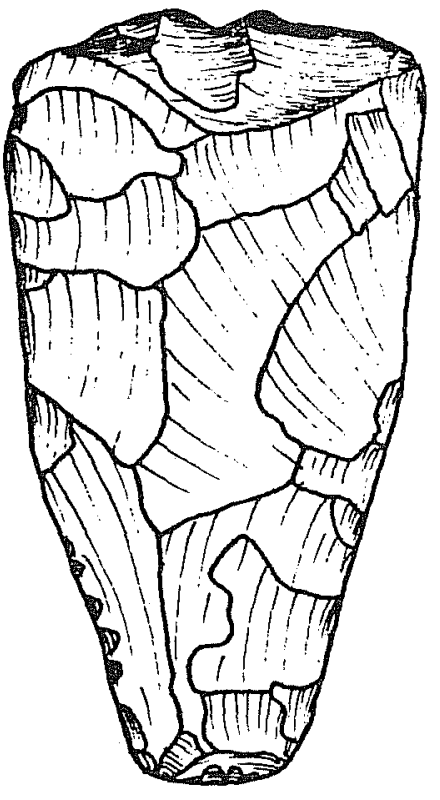

b
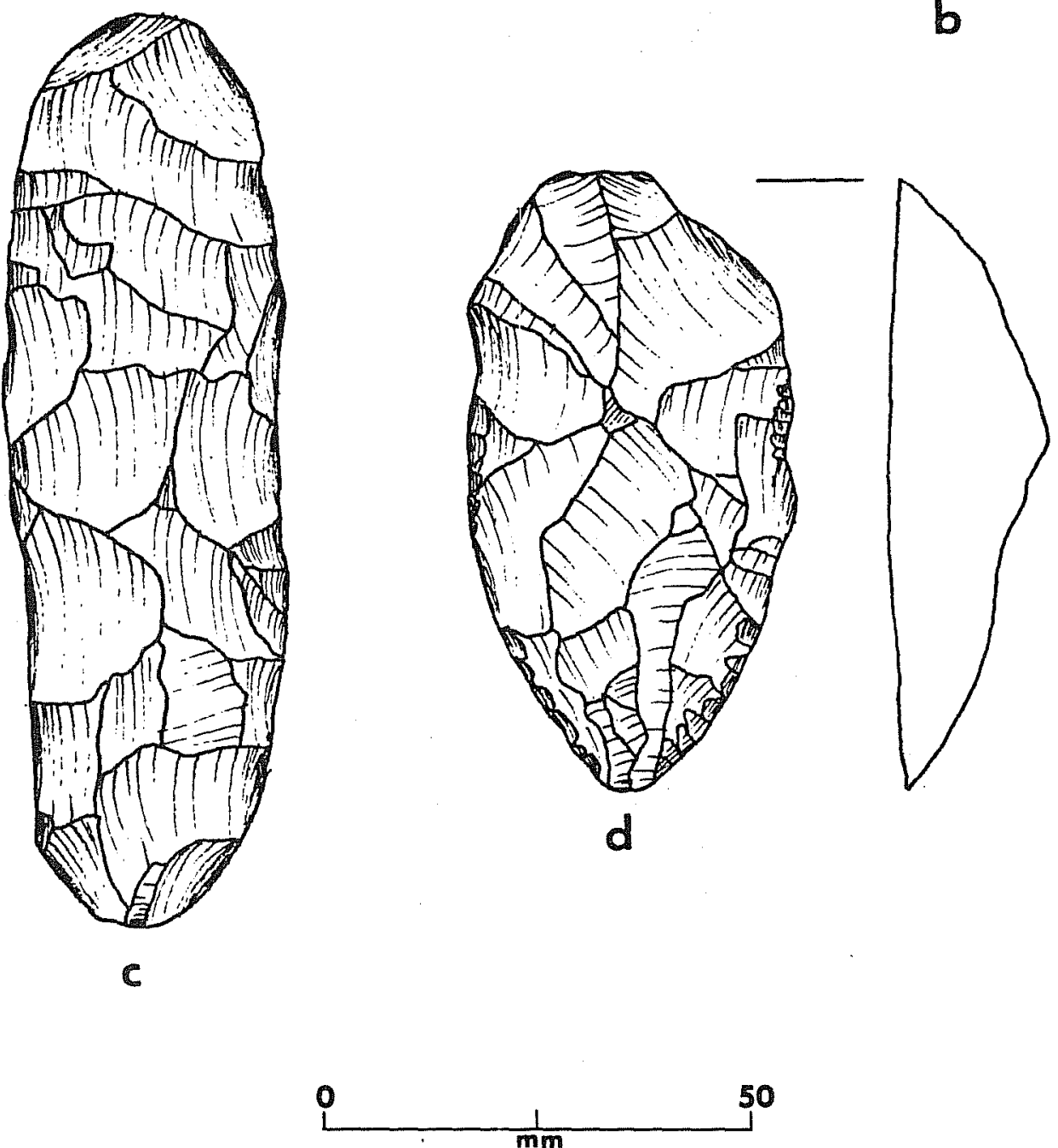


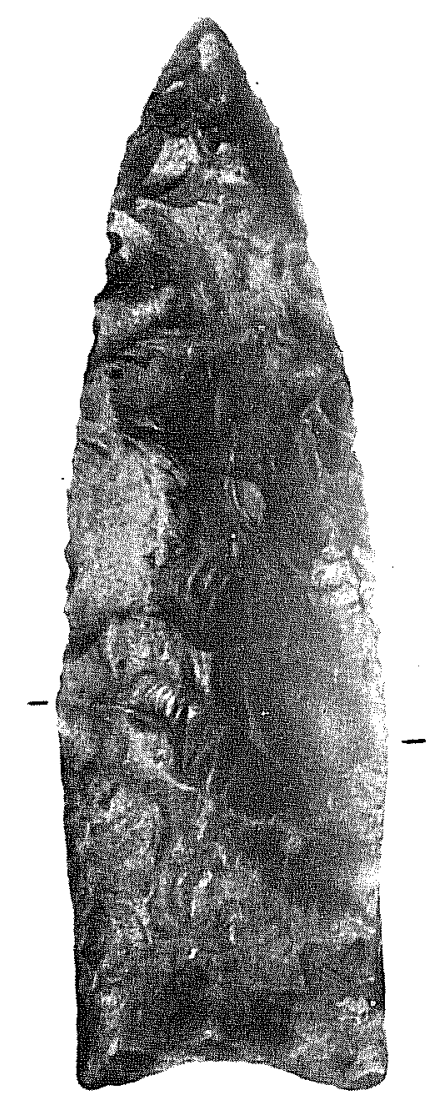

a

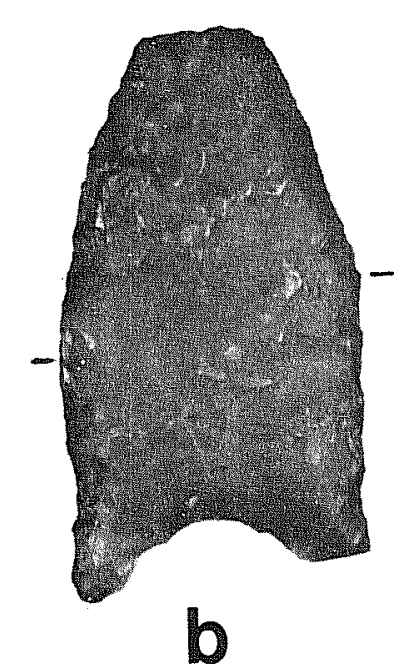

b

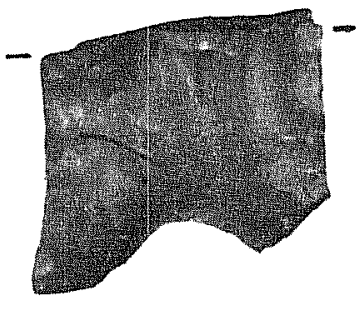

C

\section{\begin{tabular}{c|l|l|l|l|l} 
& $\mid$ & $\mid$ & $\mid$ & $\mid$ & $\mid$ \\
& 1 & 2 & 3 & 4 & 5
\end{tabular}}

Figure 8. Projectile Points from the Johnston-Heller Site. a, Plainview; b,c, Golondrina. Horizontal 1 ines indicate extent of lateral edge smoothing. 


\begin{tabular}{|c|c|c|c|}
\hline & Length & Width & Thickness \\
\hline Fig. $\begin{array}{r}5, a \\
b \\
c \\
d\end{array}$ & $\begin{array}{l}90 \\
75 \\
64 \\
89\end{array}$ & $\begin{array}{l}48 \\
40.5 \\
44.5 \\
36\end{array}$ & $\begin{array}{l}19 \\
15 \\
13 \\
17\end{array}$ \\
\hline \multirow[t]{2}{*}{ Fig. $\begin{array}{r}6, a \\
b \\
c\end{array}$} & $\begin{array}{l}90 \\
73 \\
75\end{array}$ & $\begin{array}{l}32 \\
33 \\
39\end{array}$ & $\begin{array}{l}15 \\
13 \\
15\end{array}$ \\
\hline & $\begin{array}{l}66 \\
51 \\
88\end{array}$ & $\begin{array}{l}36 \\
38.5 \\
37\end{array}$ & $\begin{array}{l}16 \\
17 \\
15\end{array}$ \\
\hline Fig. 7,b & $\begin{array}{c}77 \\
88 \\
106 \\
100 \\
85 \\
95 \\
75 \\
73 \\
90 \\
70 \\
(39) \\
47 \\
(58) \\
70 \\
68 \\
62 \\
98 \\
84 \\
76 \\
(48) \\
71\end{array}$ & $\begin{array}{l}43 \\
40.5 \\
34 \\
40 \\
39 \\
42 \\
45 \\
37 \\
30 \\
35 \\
47 \\
29 \\
38 \\
40 \\
40 \\
47 \\
36 \\
37 \\
37 \\
40 \\
31\end{array}$ & $\begin{array}{l}18 \\
17 \\
27 \\
18 \\
18 \\
25 \\
21 \\
17 \\
15 \\
15 \\
17 \\
18 \\
18 \\
13 \\
16 \\
18 \\
18 \\
19 \\
15 \\
10 \\
20\end{array}$ \\
\hline mean: & $78.4^{*}$ & 38.3 & 17.0 \\
\hline
\end{tabular}

Table 1. Dimensions of Thirty-one "Clear Fork" Tools from the JohnstonHeller Site. All measurements are in millimeters and incomplete measurements are enclosed in parentheses. Data on the five other specimens are not available.

*for complete specimens 


\begin{tabular}{|c|c|c|c|}
\hline & Length & Width & Thickness \\
\hline not illustrated 1 & $\begin{array}{l}125 \\
118\end{array}$ & $\begin{array}{l}37 \\
37\end{array}$ & $\begin{array}{l}32 \\
32\end{array}$ \\
\hline Fig. $\begin{array}{l}6, \mathrm{~d} \\
6, \mathrm{e}\end{array}$ & $\begin{array}{l}87 \\
77\end{array}$ & $\begin{array}{l}53 \\
52\end{array}$ & $\begin{array}{l}24 \\
18.5\end{array}$ \\
\hline $\begin{array}{l}\text { Fig. } 7, c \\
\text { (biface) }\end{array}$ & 106 & 33 & * \\
\hline $\begin{array}{l}\text { Fig. } 7, \mathrm{~d} \\
\text { (uniface) }\end{array}$ & 72 & 38 & 19 \\
\hline
\end{tabular}

Table 2. Dimensions of Other Unifacial and Bifacial Tools from the Johnston-Heller Site. A11 measurements are in mil1imeters.

1, 2 Guadalupe adzes or gouges

*Not available 
Length Width Thickness Length of Tateral edge smoothing

Plainview Series

R

L

$\begin{array}{lccccc}\text { Fig. } 3, b, b^{\prime} & (67.5) & 25 & 7 & 30 & 37.5 \\ \text { Fig. 8, a } & 85 & 27 & 7 & 33 & 28\end{array}$

Golondrina Series

Fig. 3 a, a'

Fig. $3 c, c^{\prime}$

Fig. $3 d, d^{\prime}$

Fig. $3 \mathrm{e}, \mathrm{e}^{\prime}$

Fig. 8 b

Fig. $8 \mathrm{c}$

$\begin{array}{ll}(80) & 25 \\ 56 & 30 \\ 55 & 26.5 \\ (51.5) & 28 \\ (45) & 25 \\ (20) & (25)\end{array}$

(25)

7
8.5
6.5
6.5
7
6

35.5

22

15

33

(28)

21
35

22.5

20.5

28

19

19

Lanceolate, Weak-Shouldered Series

Fig. 4 a, $a^{\prime}$

Fig. $4 b, b^{\prime}$

Fig. $4 c, c^{\prime}$

Fig. $4 d$, d'
76.5

70

83.5

76
29
24
26.5
27
8

7.5

8

8
20

16

26

17
17

16.5

27.5

15

Fluted Point

Fig. 7 a, a'

26

6.5

(16)

18

Table 3. Dimensions of Projectile Points from the Johnston-Heller Site. A11 measurements are in mi17imeters and incomplete measurements are enclosed in parentheses. 


\section{BIBLIOGRAPHY}

Birmingham, W. W.

1966 Distribution of the Use of Asphaltum on Projectile Points: A Request for Help. Texas Archeology 10(3): 3-5. Austin.

Epstein, J. F.

1963 The Burin-Faceted Projectile Point. American Antiquity 29: 187-201.

1969 The San Isidro Site, An Early Man Campsite in Nuevo Leon, Mexico. Anthropology Series, No. 1, University of Texas at Austin.

Haynes, C. V., Jr.

1971 Time, Environment and Early Man. Arctic Anthropology $8(2): 3-14$.

Hester, T. R.

1966 A Clovis Point from Southwest Texas. Newsbulletin, South Plains Archaeological Society 12: 2-3.

1968 Paleo-Indian Artifacts from Sites Along San Miguel Creek: Frio, Atascosa and McMullen Counties, Texas. Bulletin of the Texas Archeological Society 38.

1971 Hunters and Gatherers of the Rio Grande Plain and Lower Coast of Texas. Paper presented at annual meeting, Texas Academy of Science, Nacogdoches. (Abstract pubitished in Texas Journal of Science 23: 4): 592.

1974 On Fluted Points and South Texas Archaeology. Texas Archeology 18(2): 11-14.

Hester, T. R., D. Gilbow, and A. ATbee

1973 A Functional Analysis of "Clear Fork" Artifacts from the Rio Grande Plain, Texas. American Antiquity 38(1): $90-96$.

Hester, T. R. and T. C. Hi11, Jr.

1971 Notes on Scottsbluff Points from Southern Texas. Southwestern Lore 37: 27-33.

Hester, T. R. and H. Kohnitz

1975 Chronological Placement of "Guadalupe" Tools. La Tierra $2(2): 22-25$. 
Hester, T. R., L. White, and J. White

1969 Archeological Materials from the Oulline Site and Other Sites in La Salle County, Texas. Texas Journal of Science $21: 130-165$.

Irwin, H. T.

1971 Developments in Early Man Studies in Western North America, 1960-1970. Arctic Anthropology 8(2): 42-67.

Johnson, L., Jr.

1964 The Devil's Mouth Site. Department of Anthropology, University of Texas, Archaeology Series 6.

Kelly, T. C.

1976 Resolution of the Plainview-Golondrina Problem. Manuscript on file, Center for Archaeological Research, The University of Texas at San Antonio.

Orchard, O. D. and T. N. Campbe11

1954 Evidences of Early Man from the Vicinity of San Antonio, Texas. Texas Journal of Science 6: 454-465.

Ray, C. N.

1941 Various Types of Clear Fork Gouges. Bulletin of the Texas Archeological and Paleontological Society 13: 152-162.

Sol1berger, J. B. and T. R. Hester

1972 The Strohacker Site: A Review of Pre-Archaic Manifestations in Texas. Plains Anthropologist 17(58) Pt. 1: 326-344.

Sorrow, W. M.

1968 The Devil's Mouth Site: The Third Season-1967. Papers, Texas Archeological Salvage Project 14.

Suhm, D. A., A. D. Krieger, and E. B. Jelks

1954 An Introductory Handbook of Texas Archeology. Bulletin of the Texas Archeological Society 25.

Word, J. H. and C. L. Douglas

1970 Excavations at Baker Cave, Val Verde County, Texas. Bulletin, Texas Memorial Museum 16. 